\title{
Factors associated with the consumption of chlorine dioxide to prevent and treat COVID-19 in the Peruvian population: a cross-sectional study
}

David R. Soriano-Moreno ${ }^{1}$, Daniel Fernandez-Guzman², Fabricio Ccami-Bernal ${ }^{3}$, Cristhian Rojas-Miliano ${ }^{4}$ and Wendy Nieto-Gutierrez ${ }^{5^{*}}$ (D)

\begin{abstract}
Background: Chlorine dioxide has been promoted as an alternative for the prevention and treatment of COVID-19, especially in Peru, despite the lack of evidence to support its efficacy. This study aimed to evaluate the factors associated with chlorine dioxide consumption in the Peruvian population.

Methods: Analytical cross-sectional study. An adult Peruvian population was evaluated where chlorine dioxide consumption was divided into two groups according to the purpose of use: as prevention (individuals without COVID-19 history) and as treatment (individuals with COVID-19 history). The associated factors in each group were evaluated using Poisson regressions with the bootstrapping resampling method.

Results: Of 3610 participants included, 3213 reported no history of COVID-19, and 397 had been infected. The prevalence of chlorine dioxide consumption to prevent or treat COVID-19 was 8 and 16\%, respectively. Factors either positively or negatively associated with chlorine dioxide consumption for prevention were male sex (aPR: 1.36; 95\% Cl: 1.09-1.71), being an adult or older adult (aPR: 0.54; 95\% Cl: 0.35-0.82), having a health sciences student within the family unit (aPR: 1.38; 95\% Cl: 1.02-1.87), using medical information as the main source of information of COVID-19 (aPR: 0.57; 95\% Cl: 0.40-0.80), having comorbidities for COVID-19 (aPR: 1.36; 95\% Cl: 1.01-1.82), considering COVID-19 dangerous and deadly (aPR: 0.57; 95\% Cl: 0.45-0.74), using medications (aPR: 1.59; $95 \% \mathrm{Cl}$ : 1.25-2.06) and plants to prevent COVID-19 (aPR: 1.69; 95\% Cl: 1.21-2.36), considering chlorine dioxide ineffective (aPR: $0.18 ; 95 \% \mathrm{Cl}: 0.18-0.24$ ), and being uninformed of its efficacy (aPR: $0.21 ; 95 \% \mathrm{Cl}$ : 0.16-0.28). In addition, factors associated with chlorine dioxide consumption for treatment were considering COVID-19 dangerous and deadly (aPR: 0.56; 95\% Cl: 0.33-0.96), considering chlorine dioxide ineffective (aPR: 0.22; 95\% Cl: 0.12-0.42), and being uninformed of its efficacy (aPR: 0.15; 95\% Cl: 0.07-0.32).
\end{abstract}

\footnotetext{
*Correspondence: wendy_nieto22@hotmail.com

${ }^{5}$ Universidad San Ignacio de Loyola, Unidad de Investigación para la

Generación y Síntesis de Evidencias en Salud, Av. la Fontana 550, La Molina, Lima, Peru

Full list of author information is available at the end of the article
}

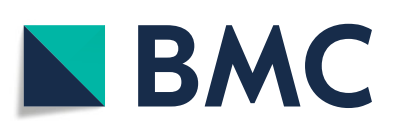

(- The Author(s). 2021 Open Access This article is licensed under a Creative Commons Attribution 4.0 International License, which permits use, sharing, adaptation, distribution and reproduction in any medium or format, as long as you give appropriate credit to the original author(s) and the source, provide a link to the Creative Commons licence, and indicate if changes were made. The images or other third party material in this article are included in the article's Creative Commons licence, unless indicated otherwise in a credit line to the material. If material is not included in the article's Creative Commons licence and your intended use is not permitted by statutory regulation or exceeds the permitted use, you will need to obtain permission directly from the copyright holder. To view a copy of this licence, visit http://creativecommons.org/licenses/by/4.0/. The Creative Commons Public Domain Dedication waiver (http://creativecommons.org/publicdomain/zero/1.0/) applies to the data made available in this article, unless otherwise stated in a credit line to the data. 
Conclusions: The prevalence of chlorine dioxide consumption to treat COVID-19 was higher than prevent. It is important to apply information strategies, prioritizing population groups with certain characteristics that are associated with a higher consumption pattern.

Keywords: COVID-19, SARS-CoV-2, Pandemic, Associated factors, Chlorine dioxide (source: MESH)

\section{Introduction}

The COVID-19 pandemic has caused millions of deaths around the world, with the Americas being the region with the highest mortality rate [1], which has generated anguish and fear in the population. This, added to the atmosphere of uncertainty and the dissemination of a large amount of false information [2], has led the population to seek and adopt remedies that promise to be wildly effective to avoid contagion or death due to COVID-19 [3], leading to the use of substances such as chlorine dioxide [2].

Chlorine dioxide is a chemical compound that occurs as a highly reactive gas, so it is generally marketed and used in its liquid form or solution known as CDS (chlorine dioxide solution) [4]. Due to its strong oxidizing power, chlorine dioxide and its derivatives are used as disinfectant agents in different industrial processes [5]; however, during the pandemic, it has been promoted as an alternative for the prevention and treatment of COVID-19, whose use has been reported by inhalation, oral and parenteral application [6]. This substance does not have sanitary approval for the prevention or treatment of any disease [7] and its efficacy has not been proven, while its risk of toxicity has been proven [8].

Peru is a country characterized by social and health inequalities [9], which have repercussions on access to health services in terms of policies, distribution of human resources, and infrastructure [10]. This, added to the widespread misinformation and promotion of pseudo-scientific therapies during the pandemic, resulted in an increased risk of ineffective and dangerous measures against COVID-19 that imply a risk to the health of citizens [2]. Even in 2021, the effects of the use of chlorine dioxide related to COVID-19 in the country have continued to be evaluated [11]. The present study aims to evaluate the factors associated with the consumption of chlorine dioxide in the Peruvian population, to foster strategies focused on the most prevalent groups, with the purpose of avoiding harmful outcomes in the population.

\section{Methodology}

\section{Study design, space, and participants}

An analytical observational study was carried out from a previously collected database, obtained to describe the prevention and control practices against COVID-19 in the Peruvian population. This study was conducted in the general adult population ( $>18$ years) of Peruvian residence and nationality in the 24 departments of the country, excluding women who reported pregnancy at the time of the survey. The survey was distributed virtually over a two-week period (September 7-21, 2020) using non-probability snowball sampling. More details about the methodology have been detailed previously [12].

\section{Questionnaire}

The questionnaire used was designed and validated by the authors and was divided into three sections: 1) general data (biological, demographic, epidemiological characteristics), 2) prevention perspectives and practices of participants without a history of COVID-19, and 3) perspectives and practices during COVID-19 infection of participants with a history of COVID-19. The first section of the questionnaire was answered by all respondents, the second section was answered only by respondents without a history of COVID-19 and the third section was answered only by respondents with a history of COVID-19 (Supplementary Material 1).

\section{Dependent variable: chlorine dioxide consumption}

The dependent variable was assessed in two populations: individuals without a history of COVID-19 and those with a history of COVID-19. For those without a history of COVID-19, chlorine dioxide consumption was assessed as COVID-19 prevention with the question "In the last 2 weeks on how many occasions have you used chlorine dioxide for COVID-19 prevention?". If the respondent answered having used it at least once, the respondent was considered to have used chlorine dioxide for prevention. For those with a history of COVID-19, chlorine dioxide consumption was assessed as a treatment of COVID-19 with the question "During your COVID-19 infection, on how many occasions have you used chlorine dioxide against COVID-19?". Chlorine dioxide was considered to have been used as a treatment if the respondent answered that it was used at least once.

\section{Statistical analysis}

The Stata v16.0 statistical package was used for data analysis. In the descriptive analysis, absolute and relative frequencies were determined. In the bivariate analysis, the chi-square test was used to compare the proportions between groups. For the evaluation of factors associated 
with chlorine dioxide consumption, Poisson regression with robust variances using the bootstrapping resampling method was used to obtain prevalence ratios (PR) with their respective $95 \%$ confidence intervals $(95 \% \mathrm{CI})$.

\section{Ethical aspects}

The primary study was evaluated and approved by the institutional ethics committee of the Universidad Peruana Unión (Certificate of Approval: 2020-CEUPeU00020). All methods were performed in accordance with the Declaration of Helsinki. Informed consent was obtained from the participants for data collection.

\section{Results}

The database used for the present study had a total of 3630 individuals (3231 without COVID-19 and 399 with COVID-19); however, 20 women were excluded because they reported being pregnant. Finally, 3610 individuals were evaluated, of whom 3213 (89\%) reported not having had a history of COVID-19 and 397 (11\%) reported having had a history of COVID-19 (Supplementary Material 2).

In the population evaluated, the majority were female (62.4 and 58.9\%), young people aged 18 to 29 years $(84.7$ and $72.8 \%$ ), with higher education (76.1 and $77.6 \%$ ), from the coastal region (48.4 and $46.1 \%$ ), from urban areas (84.8 and $83.1 \%)$, and of upper-middle social class (73.6 and 76.1\%), both for those who did not have a history of COVID-19 and those who did, respectively (Table 1).

The prevalence of chlorine dioxide consumption as a COVID-19 preventive measure was $8 \%$, with a higher prevalence of consumption observed in male individuals (9.8\%, $P=0.004)$, from the highlands or jungle region (9.8, 10.4\%, $P<0.001)$, rural area of residence $(13.9 \%$, $P<0.001)$, low social class $(10.1 \%, P=0.012)$, without a health professional in the family unit $(10.2 \%, P<0.001)$, who did not have medical information as their main source of information about COVID-19 (9.6\%, $P<$ $0.001)$, without a family member with comorbidities for COVID-19 (10.2\%, $P<0.001$ ), who considered COVID19 as a not at all or only slightly dangerous and deadly disease $(12.7 \%, P<0$. 001), who used medications as prevention for COVID-19 (14.5\%, $P<0.001)$, who used medicinal plants as prevention for COVID-19 (10.8\%, $P<$ $0.001)$, and who thought that chlorine dioxide is effective (31.6\%, $P<0.001)$ (Table 1).

Likewise, the prevalence of chlorine dioxide consumption as a treatment was $16.4 \%$, and the percentage was higher in adult individuals aged 30 years and older (25.0\%, $P=0.005)$, workers $(23.6 \%, P=0.017)$, from the jungle region $(27.9 \%, P<0.001)$, without a health professional in the family unit $(22.5 \%, P=0.036)$, who did not have medical information as their main source of information about COVID-19 (20.1\%, $P=0.001)$, with comorbidities for COVID-19 (28.6\%, $P<0.001)$, who thought that chlorine dioxide is effective $(62.1 \%, P<$ 0.001) and who thought that their case of COVID-19 was moderate-severe $(52.0 \%, P<0.001)$ (Table 1$)$.

When evaluating the factors associated with chlorine dioxide consumption as a preventive measure, we found a statistically significant association (either positive or negative) with male sex (aPR: 1.36; 95\%CI: 1.09-1.71), being an adult or older adult (over 30 years of age) (aPR: 0.54; 95\%CI: 0.35-0.82), having a health sciences student within the family unit (aPR: 1.38 ; 95\%CI: 1.02-1.87), having medical information as a source of information about COVID-19 (aPR: 0.57; 95\%CI: 0.40-0.80), having comorbidities for COVID-19 (aPR: 1.36; 95\%CI: 1.011.82), strongly considering COVID-19 to be a dangerous and deadly disease (aPR: 0.57; 95\%CI: 0.45-0.74), using medications to prevent COVID-19 (aPR: 1.59; 95\%CI: 1.25-2.06), using plants to prevent COVID-19 (aPR: 1.69; 95\%CI: $1.21-2.36)$, thinking that chlorine dioxide is not effective (aPR: 0.18 ; 95\%CI: $0.18-0.24$ ), and not being informed of the efficacy of chlorine dioxide (aPR: 0.21; 95\%CI: 0.16-0.28) (Table 2).

On the other hand, factors associated negatively with chlorine dioxide consumption as a treatment were strongly considering COVID-19 to be a dangerous and deadly disease (aPR: 0.56; 95\%CI: 0.33-0.96), thinking that chlorine dioxide is not effective (aPR: 0.22; 95\%CI: $0.12-0.42$ ), and not being informed of the efficacy of chlorine dioxide (aPR: 0.15; 95\%CI: 0.07-0.32) (Table 2).

\section{Discussion}

\section{Main findings}

The prevalence of chlorine dioxide consumption to prevent or treat COVID-19 was less than $20 \%$. The factors associated with dioxide consumption both as prevention and treatment were to consider COVID-19 a dangerous and deadly disease and the opinion of chlorine dioxide Also, we found individual variables that was associated only to chlorine dioxide consumption for prevention, like sociodemographic variables (sex and age) and health variables (source where you obtain information about COVID-19, comorbidities, and use medications and medicinal plants for prevention or treatment of COVID19).

\section{Chlorine dioxide consumption}

Chlorine dioxide is a reactive synthetic gas that has been used in the paper industry, decontamination of public buildings, and water purification [5]. Its high reactivity explains its properties to eliminate microorganisms, however, this also determines the potential adverse effects [5]. Despite this, chlorine dioxide has been promoted as a cure for diseases such as malaria, HIV and 
Table 1 Characteristics of participants according to consumption of chlorine dioxide for prevention and as a treatment against COVID-19 in the Peruvian population ( $N=3610)$

\begin{tabular}{|c|c|c|c|c|c|c|c|c|}
\hline \multirow[t]{4}{*}{ Variables } & \multicolumn{4}{|c|}{$\begin{array}{l}\text { Participants with no history of COVID-19 }(N= \\
\text { 3213) }\end{array}$} & \multicolumn{4}{|c|}{ Participants with a history of COVID-19 $(N=397)$} \\
\hline & \multirow[t]{3}{*}{$\mathrm{N}(\%)$} & \multicolumn{3}{|c|}{$\begin{array}{l}\text { Use of chlorine dioxide for COVID-19 } \\
\text { prevention }\end{array}$} & \multirow[t]{3}{*}{$\mathrm{N}(\%)$} & \multicolumn{3}{|c|}{$\begin{array}{l}\text { Use of chlorine dioxide as a treatment } \\
\text { for COVID-19 }\end{array}$} \\
\hline & & \multirow{2}{*}{$\begin{array}{l}\text { No use } \\
2956(92 \%) \\
\text { n (\%) }\end{array}$} & Use & \multirow[t]{2}{*}{$P^{a}$} & & \multirow{2}{*}{$\begin{array}{l}\text { No use } \\
332(83.6 \%) \\
\text { n (\%) }\end{array}$} & Use & \multirow[t]{2}{*}{$P^{a}$} \\
\hline & & & $\begin{array}{l}257(8 \%) \\
n(\%)\end{array}$ & & & & $\begin{array}{l}65(16.4 \%) \\
\text { n (\%) }\end{array}$ & \\
\hline \multicolumn{9}{|l|}{ Sex } \\
\hline Female & $2009(62.53)$ & $1870(93.08)$ & 139 (6.92) & \multirow[t]{2}{*}{0.004} & $234(58.94)$ & $201(85.90)$ & $33(14.10)$ & \multirow[t]{2}{*}{0.143} \\
\hline Male & $1204(37.47)$ & $1086(90.20)$ & $118(9.80)$ & & $163(41.06)$ & $131(80.37)$ & $32(19.63)$ & \\
\hline \multicolumn{9}{|l|}{ Age } \\
\hline Young (18 to 29 years old) & $2720(84.66)$ & $2494(91.69)$ & $226(8.31)$ & \multirow[t]{2}{*}{0.128} & $289(72.80)$ & $251(86.85)$ & $38(13.15)$ & \multirow[t]{2}{*}{0.005} \\
\hline Adult and older adult ( $>29$ years) & $493(15.34)$ & $462(93.71)$ & $31(6.29)$ & & $108(27.20)$ & $81(75.00)$ & $27(25.00)$ & \\
\hline \multicolumn{9}{|l|}{ Marital status } \\
\hline Single & $2829(88.05)$ & $2601(91.94)$ & $228(8.06)$ & \multirow[t]{2}{*}{0.731} & $303(76.32)$ & $256(84.49)$ & $47(15.51)$ & \multirow[t]{2}{*}{0.405} \\
\hline Married or cohabiting & $384(11.95)$ & $355(92.45)$ & $29(7.55)$ & & $94(23.68)$ & $76(80.85)$ & $18(19.15)$ & \\
\hline \multicolumn{9}{|l|}{ Education level } \\
\hline High school or less & 769 (23.93) & $709(92.20)$ & $60(7.80)$ & \multirow[t]{2}{*}{0.818} & $89(22.42)$ & $75(84.27)$ & $14(15.73)$ & \multirow[t]{2}{*}{0.852} \\
\hline Superior & $2444(76.07)$ & $2247(91.94)$ & $197(8.06)$ & & $308(77.58)$ & $257(83.44)$ & $51(16.56)$ & \\
\hline Employment status & & & & & & & & \\
\hline Not working & $2502(77.87)$ & $2308(92.25)$ & $194(7.75)$ & 0.337 & $240(60.45)$ & $212(88.33)$ & $28(11.67)$ & 0.002 \\
\hline Working & $711(22.13)$ & $648(91.14)$ & $63(8.86)$ & & $157(39.55)$ & $120(76.43)$ & $37(23.57)$ & \\
\hline Health insurance & & & & & & & & \\
\hline None & $972(30.25)$ & $889(91.46)$ & $83(8.54)$ & 0.323 & $100(25.19)$ & $88(88.00)$ & $12(12.00)$ & 0.587 \\
\hline SIS & 1199 (37.32) & $1100(91.74)$ & $99(8.26)$ & & $131(33.00)$ & $107(81.68)$ & $24(18.32)$ & \\
\hline EsSalud & $637(19.83)$ & $585(91.84)$ & $52(8.16)$ & & $101(25.44)$ & $83(82.18)$ & $18(17.82)$ & \\
\hline Others & $405(12.61)$ & $382(94.32)$ & $23(5.68)$ & & $65(16.37)$ & $54(83.08)$ & $11(16.92)$ & \\
\hline Region of residence & & & & & & & & \\
\hline Coast & $1572(48.93)$ & $1477(93.96)$ & $95(6.04)$ & $<0.001$ & $183(46.10)$ & $160(87.43)$ & $23(12.57)$ & 0.008 \\
\hline Highland & $1363(42.42)$ & $1230(90.24)$ & $133(9.76)$ & & $135(34.01)$ & $115(85.19)$ & $20(14.81)$ & \\
\hline Jungle & $278(8.65)$ & $249(89.57)$ & $29(10.43)$ & & 79 (19.90) & $57(72.15)$ & $22(27.85)$ & \\
\hline Area of residence & & & & & & & & \\
\hline Urban & $2536(84.81)$ & $2536(93.06)$ & $189(6.94)$ & $<0.001$ & $330(83.12)$ & $281(85.15)$ & $49(14.85)$ & 0.069 \\
\hline Rural & $488(15.19)$ & $420(86.07)$ & $68(13.93)$ & & $67(16.88)$ & $51(76.12)$ & $16(23.88)$ & \\
\hline Social class & & & & & & & & \\
\hline Medium-High & $2364(73.58)$ & $2192(92.72)$ & $172(7.28)$ & 0.012 & $302(76.07)$ & $253(83.77)$ & $49(16.23)$ & 0.887 \\
\hline Lower & $849(26.42)$ & $764(89.99)$ & $85(10.01)$ & & $95(23.93)$ & $79(83.16)$ & $16(16.84)$ & \\
\hline Health professional within the family & unit & & & & & & & \\
\hline No & $1250(38.90)$ & $1123(89.84)$ & $127(10.16)$ & $<0.001$ & $138(34.76)$ & $107(77.54)$ & $31(22.46)$ & 0.036 \\
\hline Student of health sciences & $513(15.97)$ & $462(90.06)$ & $51(9.94)$ & & 79 (19.90) & $66(83.54)$ & $13(16.46)$ & \\
\hline Health professional & $1450(45.13)$ & $1371(94.55)$ & $79(5.45)$ & & $180(45.34)$ & $159(88.33)$ & $21(11.67)$ & \\
\hline Source where you obtain informatior & n about COVIL & D-19 medicatio & & & & & & \\
\hline Other media & $2368(73.70)$ & $2139(90.33)$ & $229(9.67)$ & $<0.001$ & $288(72.54)$ & $230(79.86)$ & $58(20.14)$ & 0.001 \\
\hline Medical information & $845(26.30)$ & 817 (96.69) & $28(3.31)$ & & $109(27.46)$ & $102(93.58)$ & $7(6.42)$ & \\
\hline Comorbidities for COVID-19 & & & & & & & & \\
\hline No & $2743(85.37)$ & $2531(92.27)$ & $212(7.73)$ & 0.173 & $306(77.08)$ & $267(87.25)$ & $39(12.75)$ & $<0.001$ \\
\hline
\end{tabular}


Table 1 Characteristics of participants according to consumption of chlorine dioxide for prevention and as a treatment against COVID-19 in the Peruvian population ( $N=3610)$ (Continued)

\begin{tabular}{|c|c|c|c|c|c|c|c|c|}
\hline \multirow[t]{4}{*}{ Variables } & \multicolumn{4}{|c|}{$\begin{array}{l}\text { Participants with no history of COVID-19 }(N= \\
3213)\end{array}$} & \multicolumn{4}{|c|}{ Participants with a history of COVID-19 $(N=397)$} \\
\hline & \multirow[t]{3}{*}{ N (\%) } & \multicolumn{3}{|c|}{$\begin{array}{l}\text { Use of chlorine dioxide for COVID-19 } \\
\text { prevention }\end{array}$} & \multirow[t]{3}{*}{ N (\%) } & \multicolumn{3}{|c|}{$\begin{array}{l}\text { Use of chlorine dioxide as a treatment } \\
\text { for COVID-19 }\end{array}$} \\
\hline & & \multirow{2}{*}{$\begin{array}{l}\text { No use } \\
2956(92 \%) \\
\text { n (\%) }\end{array}$} & Use & \multirow[t]{2}{*}{$P^{\mathrm{a}}$} & & \multirow{2}{*}{$\begin{array}{l}\text { No use } \\
332(83.6 \%) \\
\text { n (\%) }\end{array}$} & Use & \multirow[t]{2}{*}{$P^{a}$} \\
\hline & & & $\begin{array}{l}257(8 \%) \\
\text { n (\%) }\end{array}$ & & & & $\begin{array}{l}65(16.4 \%) \\
\text { n (\%) }\end{array}$ & \\
\hline Yes & $470(14.63)$ & $425(90.43)$ & $45(9.57)$ & & $91(22.92)$ & $65(71.43)$ & $26(28.57)$ & \\
\hline \multicolumn{9}{|c|}{ Family member with comorbidity for COVID-19 } \\
\hline No & $1574(48.99)$ & $1413(89.77)$ & $161(10.23)$ & \multirow[t]{2}{*}{$<0.001$} & $181(45.59)$ & $152(83.98)$ & $29(16.02)$ & \multirow[t]{2}{*}{0.863} \\
\hline Yes & $1639(51.01)$ & $1543(94.14)$ & $96(5.86)$ & & $216(54.41)$ & $180(83.33)$ & $36(16.67)$ & \\
\hline \multicolumn{9}{|l|}{ Family member with COVID-19 diagnosis } \\
\hline No & $2385(74.23)$ & $2204(92.41)$ & $181(7.59)$ & \multirow[t]{2}{*}{0.146} & $40(10.08)$ & $33(82.50)$ & $7(17.50)$ & \multirow[t]{2}{*}{0.839} \\
\hline Yes & $828(25.77)$ & $752(90.82)$ & $76(9.18)$ & & 357 (89.92) & 299 (83.75) & $58(16.25)$ & \\
\hline \multicolumn{9}{|l|}{ Family member deceased by COVID-19 } \\
\hline No & $3171(98.69)$ & $2917(91.99)$ & $254(8.01)$ & \multirow[t]{2}{*}{0.837} & $371(93.45)$ & $313(84.37)$ & $58(15.63)$ & \multirow[t]{2}{*}{0.133} \\
\hline Yes & $42(1.31)$ & $39(92.86)$ & $3(7.14)$ & & $26(6.55)$ & $19(73.08)$ & $7(26.92)$ & \\
\hline \multicolumn{9}{|c|}{ Do you consider COVID-19 to be a dangerous and deadly disease? } \\
\hline Nothing or little & $748(23.28)$ & $653(87.30)$ & $95(12.70)$ & \multirow[t]{2}{*}{$<0.001$} & $97(24.43)$ & $75(77.32)$ & $22(22.68)$ & \multirow[t]{2}{*}{0.053} \\
\hline Much & $2465(76.72)$ & $2303(93.43)$ & $162(6.570)$ & & $300(75.57)$ & $257(85.67)$ & $43(14.33)$ & \\
\hline \multicolumn{9}{|c|}{ Use of medications for prevention or treatment of COVID-19 } \\
\hline No & $2501(77.84)$ & $2347(93.84)$ & $154(6.16)$ & \multirow[t]{2}{*}{$<0.001$} & $64(16.12)$ & $57(89.06)$ & $7(10.94)$ & \multirow[t]{2}{*}{0.199} \\
\hline Yes & $712(22.16)$ & $609(85.53)$ & $103(14.47)$ & & $333(83.88)$ & $275(82.58)$ & $58(17.42)$ & \\
\hline \multicolumn{9}{|c|}{ Use of medicinal plants for prevention or treatment of COVID-19 } \\
\hline No & $1294(40.27)$ & $1244(96.14)$ & $50(3.86)$ & \multirow[t]{2}{*}{$<0.001$} & $79(19.90)$ & $70(88.61)$ & $9(11.39)$ & \multirow[t]{2}{*}{0.181} \\
\hline Yes & 1919 (59.73) & $1712(89.21)$ & $207(10.79)$ & & $318(80.10)$ & $262(82.39)$ & $56(17.61)$ & \\
\hline \multicolumn{9}{|c|}{ Opinion of chlorine dioxide as prevention or treatment of COVID-19 } \\
\hline It is effective & $396(12.32)$ & $271(68.43)$ & $125(31.57)$ & $<0.001$ & $58(14.61)$ & $22(37.93)$ & $36(62.07)$ & $<0.001$ \\
\hline It is not effective & $1681(52.32)$ & $1614(96.01)$ & $67(3.99)$ & & $182(45.84)$ & $164(90.11)$ & $18(9.89)$ & \\
\hline I am not informed of the subject & $1136(35.36)$ & $1071(94.28)$ & $65(5.72)$ & & $157(39.55)$ & $146(92.99)$ & $11(7.01)$ & \\
\hline COVID-19 disease severity & & & & & & & & \\
\hline Mild & Not applicable & & & & $372(93.70)$ & $320(86.02)$ & $52(13.98)$ & $<0.001$ \\
\hline Moderate or severe & & & & & $25(6.30)$ & $12(48.00)$ & $13(52.00)$ & \\
\hline
\end{tabular}

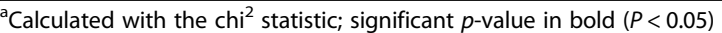

cancer, among others [13]; it has also been proposed to prevent or treat COVID-19 [14]. However, there is no evidence on the efficacy of chlorine dioxide for such purposes, but there is evidence on its harmful effects, so institutions such as the Pan American Health Organization do not recommend its use [15].

Despite this, the present study found an approximate prevalence of 8 and $16 \%$ of chlorine dioxide consumption as prevention and treatment of COVID-19, respectively. We have not found studies published in scientific journals that have evaluated the prevalence of chlorine dioxide consumption in other countries. Although a previous study indicated that chlorine dioxide consumption in Peru is high, based on the number of related media articles and blog posts, a prevalence has not been specified [16]. This assumption is in agreement with what we found, and it must be taken into account that the prevalence in our study could be underestimated, given that most of the population evaluated had characteristics in common, such as educational level, urban residence, etc., that make them less susceptible to the consumption of these substances, as has been previously reported [17].

In addition, the prevalence of chlorine dioxide consumption as a treatment is twice as high as its consumption for prevention. This could be explained by the fact 
Table 2 Factors associated with the consumption of chlorine dioxide for prevention and treatment against COVID-19 in the Peruvian population $(N=3610)$

\begin{tabular}{|c|c|c|c|c|}
\hline \multirow[t]{4}{*}{ Variables } & \multicolumn{4}{|c|}{ Chlorine dioxide consumption } \\
\hline & \multicolumn{2}{|l|}{ For prevention } & \multicolumn{2}{|l|}{ For treatment } \\
\hline & Bivariate analysis & Multivariate analysis & Bivariate analysis & Multivariate analysis \\
\hline & cPR $(95 \% \mathrm{Cl})$ & aPR $(95 \% \mathrm{Cl})$ & CPR $(95 \% \mathrm{Cl})$ & aPR $(95 \% \mathrm{Cl})$ \\
\hline \multicolumn{5}{|l|}{$\overline{\text { Sex }}$} \\
\hline Female & Ref. & Ref. & Ref. & Ref. \\
\hline Male & $1.42(1.12-1.79)$ & $1.36(1.09-1.71)$ & $1.39(0.92-2.10)$ & $1.21(0.77-1.89)$ \\
\hline \multicolumn{5}{|l|}{ Age } \\
\hline Young (18 to 29 years old) & Ref. & Ref. & Ref. & Ref. \\
\hline Adult and older adult ( $>29$ years) & $0.76(0.52-1.10)$ & $0.54(0.35-0.82)$ & $1.90(1.20-3.02)$ & $0.88(0.46-1.69)$ \\
\hline \multicolumn{5}{|l|}{ Health insurance } \\
\hline None & Ref. & Ref. & Ref. & Ref. \\
\hline SIS & $0.97(0.71-1.31)$ & $0.85(0.63-1.16)$ & $1.53(0.78-2.98)$ & $1.26(0.58-0.58)$ \\
\hline EsSalud & $0.96(0.67-1.37)$ & $1.08(0.75-1.57)$ & $1.49(0.74-2.97)$ & $1.47(0.68-3.18)$ \\
\hline Others & $0.67(0.43-1.03)$ & $0.85(0.56-1.30)$ & $1.41(0.59-3.36)$ & $1.10(0.52-2.33)$ \\
\hline \multicolumn{5}{|l|}{ Region of residence } \\
\hline Coast & Ref. & Ref. & Ref. & Ref. \\
\hline Highland & $1.61(1.24-2.10)$ & $1.23(0.94-1.60)$ & $1.18(0.66-2.11)$ & $1.14(0.61-2.12)$ \\
\hline Jungle & $1.73(1.15-2.59)$ & $1.07(0.73-1.56)$ & $2.22(1.28-3.83)$ & $1.33(0.74-2.37)$ \\
\hline \multicolumn{5}{|l|}{ Area of residence } \\
\hline Urban & Ref. & Ref. & Ref. & Ref. \\
\hline Rural & $2.01(1.53-2.63)$ & $1.22(0.93-1.61)$ & $1.61(0.97-2.66)$ & $1.1(0.54-2.21)$ \\
\hline \multicolumn{5}{|l|}{ Social class } \\
\hline Medium-High & Ref. & Ref. & Ref. & Ref. \\
\hline Lower & $1.38(1.08-1.75)$ & $0.96(0.74-1.24)$ & $1.04(0.63-1.70)$ & $0.75(0.41-1.35)$ \\
\hline \multicolumn{5}{|c|}{ Health professional within the family unit } \\
\hline No & Ref. & Ref. & Ref. & Ref. \\
\hline Student of health sciences & $0.98(0.72-1.32)$ & $1.38(1.02-1.87)$ & $0.73(0.38-1.41)$ & $0.8(0.41-1.56)$ \\
\hline Health professional & $0.54(0.40-0.72)$ & $0.79(0.58-1.06)$ & $0.52(0.31-0.87)$ & $0.64(0.39-1.06)$ \\
\hline \multicolumn{5}{|c|}{ Source where you obtain information about COVID-19 medication } \\
\hline Other media & Ref. & Ref. & Ref. & Ref. \\
\hline Medical information & $0.34(0.24-0.48)$ & $0.57(0.40-0.80)$ & $0.32(0.03-3.07)$ & $0.48(0.05-4.36)$ \\
\hline \multicolumn{5}{|l|}{ Comorbidities for COVID-19 } \\
\hline No & Ref. & Ref. & Ref. & Ref. \\
\hline Yes & $1.24(0.94-1.64)$ & $1.36(1.01-1.82)$ & $2.24(1.46-3.44)$ & $1.36(0.79-2.35)$ \\
\hline \multicolumn{5}{|c|}{ Do you consider COVID-19 to be a dangerous and deadly disease? } \\
\hline Nothing or little & Ref. & Ref. & Ref. & Ref. \\
\hline Much & $0.52(0.41-0.66)$ & $0.57(0.45-0.74)$ & $0.63(0.41-0.98)$ & $0.56(0.33-0.96)$ \\
\hline \multicolumn{5}{|c|}{ Use of medications for prevention or treatment of COVID-19 } \\
\hline No & Ref. & Ref. & Ref. & Ref. \\
\hline Yes & $2.35(1.83-3.02)$ & $1.59(1.23-2.06)$ & $1.59(0.75-3.39)$ & $2.04(0.90-4.62)$ \\
\hline \multicolumn{5}{|c|}{ Use of medicinal plants for prevention or treatment of COVID-19 } \\
\hline No & Ref. & Ref. & Ref. & Ref. \\
\hline Yes & $2.79(2.05-3.81)$ & $1.69(1.21-2.36)$ & $1.55(0.76-3.13)$ & $1.03(0.52-2.04)$ \\
\hline
\end{tabular}


Table 2 Factors associated with the consumption of chlorine dioxide for prevention and treatment against COVID-19 in the Peruvian population ( $N=3610)$ (Continued)

\begin{tabular}{|c|c|c|c|c|}
\hline \multirow[t]{3}{*}{ Variables } & \multicolumn{4}{|c|}{ Chlorine dioxide consumption } \\
\hline & \multicolumn{2}{|l|}{ For prevention } & \multicolumn{2}{|l|}{ For treatment } \\
\hline & $\begin{array}{l}\text { Bivariate analysis } \\
\text { CPR }(95 \% \mathrm{Cl})\end{array}$ & $\begin{array}{l}\text { Multivariate analysis } \\
\text { aPR }(95 \% \mathrm{Cl})\end{array}$ & $\begin{array}{l}\text { Bivariate analysis } \\
\text { CPR }(95 \% \mathrm{Cl})\end{array}$ & $\begin{array}{l}\text { Multivariate analysis } \\
\text { aPR }(95 \% \mathrm{Cl})\end{array}$ \\
\hline \multicolumn{5}{|c|}{ Opinion of chlorine dioxide as prevention or treatment of COVID-19 } \\
\hline It is effective & Ref. & Ref. & Ref. & Ref. \\
\hline It is not effective & $0.13(0.10-0.17)$ & $0.18(0.13-0.24)$ & $0.16(0.10-0.26)$ & $0.22(0.12-0.42)$ \\
\hline I am not informed of the subject & $0.18(0.14-0.24)$ & $0.21(0.16-0.28)$ & $0.11(0.06-0.22)$ & $0.15(0.07-0.32)$ \\
\hline \multicolumn{5}{|l|}{ COVID-19 disease severity } \\
\hline Mild & Not applicable & & Ref. & Ref. \\
\hline Moderate or severe & & & $3.72(2.24-6.17)$ & $1.45(0.69-3.04)$ \\
\hline
\end{tabular}

CPR Crude prevalence ratio, aPR Adjusted prevalence ratio, 95\% Cl 95\% confidence interval, Ref. reference group

that the diagnosis of COVID-19 can generate greater anxiety [18], and, therefore, desperation to act against the condition, leading to a greater susceptibility to consume this type of substance that is sold as a "miracle cure" for the disease [19]. Both as prevention or treatment of COVID-19, the consumption of this substance can have fatal consequences. On the one hand, those who use it for prevention may neglect adherence to truly effective preventive measures, such as social distancing or the use of masks. On the other hand, those who use it for treatment may tend to experience additional complications due to the delay in seeking health care. Taking into account that in both cases there may also be cases of intoxication, its consumption has implications not only for health but also for higher healthcare costs and a greater burden on health systems [20].

\section{Factors associated with chlorine dioxide consumption}

It was found that male participants consumed chlorine dioxide more frequently to prevent COVID-19. However, studies that evaluated the consumption of other substances (drugs) found no significant differences between the sexes $(p>0.05)$ [21]. Studies in other countries even found an association between female sex and the use of other substances (drugs, traditional medicine, vitamin C) for COVID-19 prevention $(p<0.05)$ [22]. This suggests the existence of factors specific to chlorine dioxide implicated in its higher consumption among the male population, such as the fact that the promoters of this substance were of the same sex, which may generate empathy in their peers [23]. Additionally, in Peru, according to the National Institute of Statistics and Informatics, men work more than women [24], a fact that could have led them to seek multiple prevention alternatives due to their greater exposure to COVID-19.

Likewise, it was found that being older than 30 years was associated with lower consumption of chlorine dioxide as prevention of COVID-19. In contrast to this, previous studies found heterogeneous results regarding the direction between age and the use of unconventional medical practices [25]. However, for this study, the association found is possibly due to the fact that older people do not rely as much on chemical products and prefer more natural alternatives for this purpose [26]. Another factor that could explain our result is that the older population in Peru does not usually use social networks as an informative medium [27], and this was the main source where campaigns promoting the use of chlorine dioxide were promoted [6], so they may have had less exposure to news promoting its use. However, some studies suggest that fake news may have a greater reach in older populations [28]. For this reason, governments should warn against waves of misinformation from popular social networks and other media.

Among the family factors studied, it was reasonable to expect that family members of health science students would have a lower prevalence of the use of substances without scientific evidence, such as chlorine dioxide. However, it was found that having a health sciences student increased the prevalence of consuming this substance to prevent COVID-19. This could be explained by the fact that at the family level the transmission of health information is based on experience, values, and customs [29], given that processes and ideologies that seek to protect health and manage disease triggers are developed in the domestic sphere [30]. In addition, the inexperience of the future physicians may have contributed to the use of chlorine dioxide by the other members. On the other hand, although in the bivariate analysis the presence of a health professional in the home was associated with a lower frequency of chlorine dioxide use, this was not the case when adjusted for the other variables. This could be due to the abundance of popular and scientific information without adequate 
quality [31], as well as a deficit in the applicability of the judicious use of evidence in health professionals in general [32].

Furthermore, it is noteworthy that having medical information (and not health professionals in general) as the main source of information about COVID-19 was associated with a lower prevalence of using chlorine dioxide as a preventive, which could be explained by the quality of information that a physician could provide about the false claims of chlorine dioxide. Also, the lack of an adequate source of information led many people to believe the sensationalist explanations of the product [33]. However, in the case of those who took chlorine dioxide as a treatment measure, the source of information was not associated, which leads us to believe that the fear of worsening or death from COVID-19 infection was greater and sufficient to influence their consumption, despite having received adequate information.

An interesting finding is that having comorbidities was associated with higher consumption of chlorine dioxide as COVID-19 prevention. These patients have a higher risk of mortality from COVID-19 [34], in addition to the fact that measures to treat their diseases may lead them to expose themselves more and decrease their preventive practices against COVID-19 [35]. Feeling more susceptible, the concern may lead them to seek complementary measures [36] such as evidence-free solutions to prevent the disease.

However, in the face of a disease detected as a threat, perceived susceptibility does not act the same as perceived severity [37]. In our study, people who considered COVID-19 a dangerous and deadly disease consumed less chlorine dioxide for prevention and treatment. This is similar to a study where it was found that being aware of COVID-19 severity may predict greater adherence to recommended prevention practices [38]. Both perceived severity and susceptibility depend on knowledge about the condition [37], so again, it is important to make efforts to combat infodemia and improve knowledge in the population so that people can improve their health practices and be able to recognize the ineffectiveness of practices without scientific evidence.

Concerning the use of other substances, it was found that the use of medicines and medicinal plants to prevent COVID-19 was associated with higher consumption of chlorine dioxide as a preventive measure. The use of medicinal plants [39] and self-medication are common practices in Peru, especially during the pandemic [21]. However, the fact that people consume one of these measures does not mean that they trust in its efficacy [40] leading them to seek more than one preventive measure such as medicines and to rely on pseudoscientific beliefs such as the consumption of chlorine dioxide [36]. This practice may result in the population having a false sense of security and relaxing preventive measures against COVID-19 [41].

It is crucial to highlight the importance of educating the population, which with an adequate source of information can learn about the damage that chlorine dioxide can have and its lack of benefits for COVID-19. As observed in our study, the belief that chlorine dioxide is not effective is associated with a lower consumption as prevention and treatment of COVID-19. The consumption of chlorine dioxide and its associated factors should be evaluated in other countries that have been under similar social and political influences as Peru. Information should be regulated by the media following the recommendations of institutions such as the Pan American Health Organization, which does not recommend chlorine dioxide, and not pseudoscientists.

\section{Limitations and strengths}

The present study has limitations that should be taken into account. First, the non-probabilistic sampling used makes it difficult to extrapolate the prevalences of chlorine dioxide consumption found, since, in the sample studied, the high percentage of women would decrease them, while the high percentage of young people would increase them. Secondly, the survey was distributed virtually and to acquaintances of the authors and collaborators of the study, a fact that could have led to the characteristics found in the sample studied (high percentage of young people, with higher education and from the urban sector). Thirdly, the sample of patients with a history of COVID-19 was considerably smaller than those without COVID-19, making the estimates for the first group more imprecise. Fourthly, this study was a secondary analysis of previously collected data where excluded pregnant, for this reason, we can't extrapolate our results to this specific population. However, the inclusion of this population could underestimate our general prevalence, because the women are more cautious in their decision about what things they can ingest.

Despite this, this study evaluated a total of 3610 individuals, including respondents with and without a history of COVID-19, from the 24 departments of Peru, and to our knowledge, this is the first study that evaluates the factors associated with chlorine dioxide consumption in the general Peruvian population, revealing a real public health problem.

\section{Conclusions}

The prevalence of chlorine dioxide consumption among the Peruvian sample evaluated to prevent or treat COVID-19 was 8 and 16\%, respectively. Considering COVID-19 dangerous and deadly, and considering that chlorine dioxide is not effective or not being informed of its efficacy were associated with lower consumption, 
both to prevent and treat COVID-19. Therefore, it is suggested to continue educating the population to avoid the consumption of this type of substance and the implementation of policies to regulate the information propagated by the media, to mitigate false news and promote evidence-based recommendations.

\section{Supplementary Information}

The online version contains supplementary material available at https://doi. org/10.1186/s12889-021-12191-9

Additional file 1.

Additional file 2.

\section{Acknowledgments}

Special thanks to Michael White, Universidad Peruana Unión, who provided support by reviewing the draft of this article.

\section{Authors' contributions}

DRSM and DFG developed the research idea. WNG, DRSM and DFG performed the statistical analysis. All of the authors drafted the manuscript and participated in the revision and approval of the final manuscript.

\section{Funding}

None.

\section{Availability of data and materials}

All data generated or analysed during this study are included in this published article and its supplementary information files.

\section{Declarations}

\section{Ethics approval and consent to participate}

The primary study was evaluated and approved by the institutional ethics committee of the Universidad Peruana Unión (Certificate of Approval: 2020CEUPeU-00020). All methods were performed in accordance with the Declaration of Helsinki. Informed consent was obtained from the participants for data collection.

\section{Consent for publication}

Not applicable.

\section{Competing interests}

None declared.

\section{Author details}

'Unidad de Investigación Clínica y Epidemiológica, Escuela de Medicina, Universidad Peruana Unión, Lima, Peru. ${ }^{2}$ Grupo Peruano de Investigación Epidemiológica, Unidad para la Generación y Síntesis de Evidencias en Salud Universidad San Ignacio de Loyola, Lima, Peru. ${ }^{3}$ Universidad Nacional de San Agustín de Arequipa, Arequipa, Peru. ${ }^{4}$ Universidad Nacional del Centro del Peru, Huancayo, Peru. ${ }^{5}$ Universidad San Ignacio de Loyola, Unidad de Investigación para la Generación y Síntesis de Evidencias en Salud, Av. la Fontana 550, La Molina, Lima, Peru.

Received: 31 May 2021 Accepted: 8 November 2021

Published online: 17 November 2021

\section{References}

1. Weekly epidemiological update - 5 January 2021. https:/www.who.int/ publications/m/item/weekly-epidemiological-update\%2D\%2D-5-january-2 021. Accessed 10 Jan 2021

2. Vega-Dienstmaier JM. Teorías de conspiración y desinformación entorno a la epidemia de la COVID-19. Rev Neuropsiquiatr. 2020:83(3):135-7. https:// doi.org/10.20453/rnp.v83i3.3792.
3. Escobedo AA, Rodríguez-Morales AJ, Almirall P, Almanza C, Rumbaut R. SARS-CoV-2/COVID-19: evolution in the Caribbean islands. Travel Med Infect Dis. 2020;37:101854. https://doi.org/10.1016/j.tmaid.2020.101854.

4. Kály-Kullai K, Wittmann M, Noszticzius Z, Rosivall L. Can chlorine dioxide prevent the spreading of coronavirus or other viral infections? Medical hypotheses. Physiol Int. 2020;107(1):1-11. https://doi.org/10.1556/2060.2020.00015.

5. Resumen de Salud Pública: Dióxido de cloro y clorito (Chlorine Dioxide and Chlorite) | PHS | ATSDR. 2021. https://www.atsdr.cdc.gov/es/phs/es_phs160. html. Accessed 21 Feb 2021

6. Huquillanqui F. Coronavirus en Perú | Dióxido de cloro es vendido ilegalmente a través de redes sociales como cura de la COVID-19. RPP Noticias. 2020; https://rpp.pe/lima/actualidad/coronavirus-en-peru-dioxidode-cloro-es-vendido-ilegalmente-a-traves-de-redes-sociales-como-cura-de-lacovid-19-noticia-1282416. Accessed 10 Jan 2021

7. Dirección General de Medicamentos, Insumos y Drogas. Consumo de dióxido de cloro o clorito de sodio es peligroso para la salud. DIGEMID. 2020; http://www.digemid.minsa.gob.pe/main.asp? Seccion=3\&ldltem=2215. Accessed 10 Jan 2021

8. Coronavirus (COVID-19) Update: FDA Warns Seller Marketing Dangerous Chlorine Dioxide Products that Claim to Treat or Prevent COVID-19 | FDA. U. S. Food \& Drug Administration. 2020. https://www.fda.gov/news-events/ press-announcements/coronavirus-covid-19-update-fda-warns-seller-ma rketing-dangerous-chlorine-dioxide-products-claim. Accessed 10 Jan 2021.

9. Villar-mayuntupa G, Villar-mayuntupa G. Health care and Global Health Covid-19 y la desigualdad en el Perú. Peruvian J Health Care Glob Health. 2020:4:4-5.

10. Aravena-Rivas Y, Carbajal-Rodríguez G. Geographical and socioeconomic inequalities in dental attendance among children in Peru: findings from the demographic and family health survey 2017. Community Dent Oral Epidemiol. 2021:49(1):78-86. https://doi.org/10.1111/cdoe.12580.

11. PERÚ EP de SESAE. Congreso aprobó creación de comisión que investigará efectos del dióxido de cloro. https://andina.pe/agencia/noticia-congreso-a probo-creacion-comision-investigara-efectos-del-dioxido-cloro-845095.aspx. Accessed 18 May 2021

12. Fernandez-Guzman D, Soriano-Moreno D, Ccami-Bernal F, Rojas-Miliano C, Sangster-Carrasco L, Hernández-Bustamante E, et al. Prácticas de prevención y control frente a la infección por Sars-Cov2 en la población peruana. Rev Cuerpo Méd Hosp Nac Almanzor Aguinaga Asenjo. 2021;14(Sup1):13-21. https://doi.org/10.35434/rcmhnaaa.2021.14Sup1.1149.

13. The Master Mineral Solution of the Third Millennium. https://books.apple. $\mathrm{com} / \mathrm{gb} / \mathrm{book} /$ the-master-mineral-solution-of-the-third-millennium/id4 57777697. Accessed 21 Feb 2021.

14. Karnik-Henry MS. Acidified sodium chlorite solution: A potential prophylaxis to mitigate impact of multiple exposures to COVID-19 in frontline healthcare providers. Hosp Pract (1995). 2020:48:165-8.

15. de la SOP. La OPS no recomienda tomar productos que contengan dióxido de cloro, clorito de sodio, hipoclorito de sodio o derivados, 16 de julio de 2020. Procedures, manuals, guidelines. OPS. 2020 https://iris.paho.org/ha ndle/10665.2/52484. Accessed 30 Jan 2021.

16. Mostajo-Radji M. Pseudoscience in the times of crisis: How and why chlorine dioxide consumption became popular in Latin America during the COVID-19 pandemic. 2020. https://doi.org/10.31235/osf.io/u9ehf.

17. Jamhour A, El-Kheir A, Salameh P, Hanna PA, Mansour H. Antibiotic knowledge and self-medication practices in a developing country: a crosssectional study. Am J Infect Control. 2017;45(4):384-8. https://doi.org/10.101 6/j.ajic.2016.11.026

18. Taquet M, Luciano S, Geddes JR, Harrison PJ. Bidirectional associations between COVID-19 and psychiatric disorder: retrospective cohort studies of 62354 COVID-19 cases in the USA. Lancet Psychiatry. 2021;8(2):130-40. https://doi.org/10.1016/S2215-0366(20)30462-4

19. Latina A. el negocio del dióxido de cloro, el supuesto producto "milagroso" contra el Covid-19. France 24; 2020. https://www.france24.com/es/2020072 7-latinoamérica-negocio-dióxido-cloro-cura-covid19. Accessed 2 Feb 2021

20. Khatony A, Soroush A, Andayeshgar B, Abdi A. Nursing students' perceived consequences of self-medication: a qualitative study. BMC Nurs. 2020;19(1): 71. https://doi.org/10.1186/s12912-020-00460-8.

21. Quispe-Cañari JF, Fidel-Rosales E, Manrique D, Mascaró-Zan J, HuamánCastillón KM, Chamorro-Espinoza SE, et al. Self-medication practices during the COVID-19 pandemic among the adult population in Peru: A crosssectional survey. Saudi Pharm J. 2020. https://doi.org/10.1016/j.jsps.2020.12. 001. 
22. Sadio AJ, Gbeasor-Komlanvi FA, Konu RY, Bakoubayi AW, Tchankoni MK, Bitty-Anderson AM, et al. Assessment of self-medication practices in the context of the COVID-19 outbreak in Togo. BMC Public Health. 2021;21(1): 58. https://doi.org/10.1186/s12889-020-10145-1.

23. Chekijian S, Kinsman J, Taylor RA, Ravi S, Parwani V, Ulrich A, et al. Association between patient-physician gender concordance and patient experience scores. Is there gender bias? Am J Emerg Med. 2020. https://doi. org/10.1016/j.ajem.2020.09.090.

24. INEI :: Perú: Indicadores de Empleo e Ingresos por Departamentos, 20072017. https://www.inei.gob.pe/media/MenuRecursivo/publicaciones_digita les/Est/Lib1537/index.html. Accessed 2 Feb 2021.

25. Bishop FL, Lewith GT. Who uses CAM? A narrative review of demographic characteristics and health factors associated with CAM use. Evid Based Complement Alternat Med. 2010;7(1):11-28. https://doi.org/10.1093/ecam/ nen023.

26. Zörgő S, Peters G-JY, Mkhitaryan S. Attitudes underlying reliance on complementary and alternative medicine. Integr Cancer Ther. 2020;19: 1534735420910472. https://doi.org/10.1177/1534735420910472.

27. Rivas-Nieto AC, Málaga G, Ruiz-Grosso P, Huayanay-Espinoza CA, Curioso WH. Uso y percepciones de las tecnologías de información y comunicación en pacientes con hipertensión arterial, dislipidemia o diabetes de un hospital nacional de Lima, Perú. Rev Peru Med Exp Salud Publica. 2015;32(2): 283-8. https://doi.org/10.17843/rpmesp.2015.322.1621.

28. Loos E, Nijenhuis J. Consuming Fake News: A Matter of Age? The Perception of Political Fake News Stories in Facebook Ads. In: Gao Q, Zhou J, editors. Human Aspects of IT for the Aged Population. Technology and Society. Cham: Springer International Publishing; 2020. p. 69-88. https://doi. org/10.1007/978-3-030-50232-4_6.

29. Placeres Hernández JF, de León RL, Delgado HI. La familia y el adulto mayor. Rev Méd Electrón. 2011;33:472-83.

30. del C Cid Rodríguez M, Montes de Oca Ramos R, Hernandez Díaz O. La familia en el cuidado de la salud. Rev Méd Electrón. 2014;36:462-72.

31. Alvarez-Risco A, Mejia CR, Delgado-Zegarra J, Del-Aguila-Arcentales S, ArceEsquivel AA, Valladares-Garrido MJ, et al. The Peru approach against the COVID-19 Infodemic: insights and strategies. Am J Trop Med Hyg. 2020; 103(2):583-6. https://doi.org/10.4269/ajtmh.20-0536.

32. Nieto-Gutierrez W, Zafra-Tanaka JH, Pacheco-Barrios K, Taype-Rondan A. Selfperception of competences in clinical practice among recently graduated physicians from Lima, Peru. Heliyon. 2020;6(11):e05424. https://doi.org/10.1 016/j.heliyon.2020.e05424.

33. Burela A, Hernández-Vásquez A, Comandé D, Peralta V, Fiestas F. Dióxido de cloro y derivados del cloro para prevenir o tratar la COVID-19: revisión sistemática. Rev Peru Med Exp Salud Pública. 2020;37(4):605-10. https://doi. org/10.17843/rpmesp.2020.374.6330.

34. Covid-19: risk factors for severe disease and death | The BMJ. https://www. bmj.com/content/368/bmj.m1198.long. Accessed 2 Feb 2021.

35. Vordenberg SE, Zikmund-Fisher BJ. Older adults' strategies for obtaining medication refills in hypothetical scenarios in the face of COVID-19 risk. J Am Pharm Assoc (2003). 2020;60:915-922.e4

36. Escolà-Gascón Á, Marín F-X, Rusiñol J, Gallifa J. Evidence of the psychological effects of pseudoscientific information about COVID-19 on rural and urban populations. Psychiatry Res. 2021;295:113628. https://doi. org/10.1016/j.psychres.2020.113628.

37. Glanz K, Rimer BK, Viswanath K. Health Behavior and Health Education: Theory, Research, and Practice: John Wiley \& Sons; 2008.

38. Jose R, Narendran M, Bindu A, Beevi N. L M, Benny PV. Public perception and preparedness for the pandemic COVID 19: a health belief model approach. Clin Epidemiol Glob Health. 2021;9:41-6. https://doi.org/10.1016/j. cegh.2020.06.009.

39. Valenzuela-Oré F, Romaní-Romaní F, Monteza-Facho BM, Fuentes-Delgado D, Vilchez-Buitron E, Salaverry-García O. Prácticas culturales vinculadas al cuidado de la salud y percepción sobre la atención en establecimientos de salud en residentes de centros poblados alto-andinos de Huancavelica, Perú. Rev Peru Med Exp Salud Publica. 2018;35(1):84-92. https://doi.org/10.1 7843/rpmesp.2018.351.3603.

40. Moyce S, Velazquez M, Claudio D, Thompson S, Metcalf M, Aghbashian E, et al. Exploring a rural Latino community's perception of the COVID-19 pandemic. Ethn Health. 2020:1-13.

41. Soto A, Soto A. El uso de drogas sin efecto demostrado como estrategia terapéutica en COVID-19 en el Perú. Acta Méd Peru. 2020:37(3):255-7. https://doi.org/10.35663/amp.2020.373.1548.

\section{Publisher's Note}

Springer Nature remains neutral with regard to jurisdictional claims in published maps and institutional affiliations.
Ready to submit your research? Choose BMC and benefit from:

- fast, convenient online submission

- thorough peer review by experienced researchers in your field

- rapid publication on acceptance

- support for research data, including large and complex data types

- gold Open Access which fosters wider collaboration and increased citations

- maximum visibility for your research: over $100 \mathrm{M}$ website views per year

At BMC, research is always in progress.

Learn more biomedcentral.com/submissions 